\title{
Analisis Premi Asuransi Jiwa Menggunakan Model Cox Proportional Hazard
}

\author{
Firda Anisa Fajarini ${ }^{1}$ and Mohamat Fatekurohman ${ }^{2}$ \\ ${ }^{1,2}$ Jurusan Matematika, Fakultas Matematika dan Ilmu Pengetahuan Alam, Universitas Jember \\ mfatekurohman.fmipa@unej.ac.id
}

\begin{abstract}
Cox proportional hazard model is a regression model that is used to see the factors that cause an event. The survival analysis used in this research is the period of time the client is able to pay the life insurance premium using Cox proportional hazard model with Breslow method.The purpose of this research is to know how sex, age, insured money, job, method of payment of premium, premium, and type of product can influence the level of ability of client to make payment of life insurance premium based on customer data from PT. BRI Life Insurance Branch of Jember in 2007. The result of this research is the final model of Cox proportional hazard obtained from several variables which have significant influence with simultaneous and partial significance test is the variable of insured money $\left(X_{3}\right)$, variable of payment method of premium $\left(X_{5}\right)$, premium variable $\left(X_{6}\right)$, and insurance product variable $\left(X_{7}\right)$. The four variables are said to have a significant effect on the model, so that the final model of Cox proportional hazard is obtained that consists of the parameter estimation $(\beta)$ value of each variable
\end{abstract}

Keywords : survival analysis, cox proportional hazard model, breslow method, life insurance.

\section{Pendahuluan}

Asuransi jiwa merupakan jenis asuransi untuk memproteksi jiwa seseorang dan berhubungan dengan ketahanan tubuh seseorang. Risiko yang mungkin timbul pada asuransi jiwa terutama terletak pada unsur waktu (time) [1]. Secara garis besar menjadi nasabah asuransi wajib melakukan pembayaran premi agar asuransi yang diikuti dapat digunakan sesuai manfaat. Apabila nasabah asuransi tidak melakukan pembayaran sesuai dengan ketentuan dan jangka waktu yang sudah ditentukan, maka akan terjadi beberapa event (status polis) pada asuransi tersebut. Permasalahan yang dilibatkan dalam penelitian ini yaitu asuransi jiwa karena asuransi jiwa memperhitungkan proteksi jiwa atau memperhitungkan kapan seseorang akan meninggal dan dapat bertahan maka diperlukan suatu analisis yang berhubungan dengan waktu. Waktu yang digunakan dalam penelitian ini yaitu jangka waktu kemampuan nasabah dalam membayar premi. Jangka waktu kemampuan nasabah dalam membayar premi ditentukan oleh lamanya nasabah asuransi melakukan pembayaran premi mulai dari awal menjadi nasabah asuransi hingga melakukan pembayaran premi terakhir. Pengaruh faktor-faktor pada penelitian ini dikaji menggunakan model Cox proportional hazard dengan metode Breslow khususnya pada data tersensor kanan tipe 1 yang berguna untuk mengetahui tingkat kemampuan nasabah 
dalam melakukan pembayaran premi asuransi agar sesuai dengan masa pembayaran asuransi yang telah ditentukan.

2. Analisis Survival. Analisis survival atau analisis ketahanan hidup adalah analisis data yang berhubungan dengan waktu, mulai dari awal sampai terjadinya suatu peristiwa [2]. Jangka waktu dari awal dilakukan pengamatan pada suatu individu (time origin) sampai terjadinya suatu peristiwa khusus (end point atau failure event) disebut dengan waktu survival. Fungsi-fungsi pada distribusi waktu survival merupakan suatu fungsi yang menggunakan variabel random waktu survival. Variabel random biasanya dinotasikan dengan huruf $\mathrm{T}$.

2.1. Data Tersensor. Data tersensor merupakan data yang tidak dapat diamati secara utuh dikarenakan subyek pengamatan hilang sehingga tidak dapat diambil datanya, atau sampai akhir penelitian subyek tersebut belum mengalami suatu event tertentu [3]. Ada tiga alasan terjadinya suatu penyensoran [4], yaitu:

1. Subyek pengamatan yang diamati tidak mengalami suatu event sampai penelitian berakhir (loss to follow-up).

2. Subyek pengamatan hilang selama penelitian.

3. Subyek pengamatan ditarik dari penelitian karena suatu peristiwa. Macam-macam penyensoran [2], yaitu:

1. Tersensor kanan terdapat dua jenis atau tipe, yaitu tersensor kanan tipe 1 tersensor karena tidak mengalami kejadian sampai akhir masa penelitian, tersensor kanan tipe 2 tersensor karena tidak bisa mengikuti pengamatan sampai akhir akibat adanya kejadian lain di luar yang menjadi perhatian.

2. Tersensor kiri terjadi ketika subyek pengamatan tidak teramati pada awal waktu pengamatan, akan tetapi sebelum penelitan berakhir semua event sudah dapat diamati secara penuh.

Tersensor interval terjadi ketika suatu event yang diamati pada subyek pengamatan terjadi pada selang waktu tertentu.

2.2. Metode Kaplan Meier. Metode Kaplan Meier digunakan untuk menaksir fungsi survival dan fungsi hazard. Metode ini disebut juga metode nonparametrik karena tidak membutuhkan asumsi distribusi dari waktu survival [5].

1. Taksiran fungsi survival, misalkan terdapat $n$ individu dengan waktu survival yaitu Beberapa pengamatan ini tersensor jika terdapat $r$ waktu failure diantara $n$ individu, dengan $r \leq n$, maka waktu failure ke-j ditunjukkan sebagai $t_{(j)}$, untuk $j=1,2, \ldots, r$ 
untuk $k \leq r$. Estimasi fungsi survival pada waktu ke- $k$ adalah

$$
\hat{S}(t)=\prod_{j=1}^{k}\left(\frac{n_{j}-d_{j}}{n_{j}}\right)
$$

2. Taksiran fungsi hazard, menaksir fungsi hazard dari waktu survival menggunakan rasio jumlah failure terhadap jumlah individu yang berada pada risiko failure. Estimasi fungsi hazard yaitu:

$$
\hat{h}(t)=\frac{d_{j}}{n_{j}}
$$

Fungsi survival memiliki hubungan dengan fungsi hazard yaitu pada fungsi hazard kumulatif. Nilai taksiran fungsi hazard kumulatif yaitu,

$$
\widehat{H}(t)=-\log (S(t))
$$

2.3. Asumsi Proportional Hazard. Ada tiga pendekatan umum untuk menaksir asumsi proportional hazard pada model Cox [6], yaitu:

1. Grafik (Graphical)

Terdapat dua jenis grafik yang dapat digunakan dalam pengujian asumsi proportional hazard yaitu grafik plot $\ln (-\ln S(t))$ terhadap waktu survival dan plot Kaplan-Meier pengamatan (observed) serta prediksi (expected) dari model Cox proportional hazard.

2. Goodness-of-fit-test merupakan salah satu pendekatan secara statistika dengan menguji korelasi antara variabel residu Schoenfeld dan rank waktu survival. Kriteria uji yang digunakan yaitu $H_{0}$ diterima apabila nilai $p$-value $>\alpha=0,05$.

\section{Time-dependent Variables}

Uji asumsi proportional hazard dengan time-dependent variables menggunakan model Cox extended yang melibatkan fungsi waktu.

2.4. Model Cox Proportional Hazard. Cox proportional hazard merupakan model regresi yang digunakan untuk melihat faktor-faktor yang menyebabkan terjadinya suatu peristiwa biasa dikenal dengan nama (time-dependent covariate) dengan peubah respon adalah waktu ketahanan hidup. Model regresi Cox merupakan model regresi yang menyatakan tingkat hazard (risiko) dari individu dengan karakteristik tertentu yang disebut kovariat [7]. Model Cox [4]:

dengan,

$$
h(t, x)=h_{0}(t) \exp \left(\beta_{1} x_{1}+\beta_{2} x_{2}+\ldots+\beta_{p} x_{p}\right)
$$

$h_{0}(t) \quad$ : fungsi dasar hazard,

$\beta_{1} \beta_{2, m}, \beta_{p}$ : parameter regresi, 


$$
x_{1}, x_{2, m}, x_{p}: \text { nilai variabel bebas } X_{1_{s}} X_{2, m}, X_{p}
$$

2.5. Uji Signifikansi Parameter. Uji signifikansi parameter digunakan untuk mengetahui ada tidaknya hubungan parameter di dalam model regresi Uji signifikansi dilakukan secara serentak maupun parsial.

1. Uji Signifikansi Serentak

Uji serentak dilakukan untuk signifikansi parameter model regresi secara bersama-sama. Prosedur pengujian parameter secara serentak adalah sebagai berikut:

Hipotesis :

$H_{0}: \beta_{1}=\beta_{2}=\ldots=\beta_{p}=0$

$H_{1}$ : Paling tidak ada satu $\beta_{k} \neq 0$ untuk $k=1,2, \ldots, p$

Taraf signifikansi $\alpha=0,05$

Statistik uji:

$$
G^{2}=-2 \ln \left(\frac{L(\hat{\Omega})}{L(\hat{\omega})}\right)=-2[\ln L(\widehat{\Omega})-\ln L(\widehat{\omega})]
$$

Penentuan titik kritik

Tolak $H_{0}$ jika $G_{\text {hitung }}^{2}>\chi_{(p, \pi)}^{2}$ atau $p$-value $<\alpha$

2. Uji Signifikansi Parsial

Uji signifikansi secara parsial digunakan untuk mengetahui covariate yang berpengaruh terhadap model regresi. Prosedur pengujian parameter secara parsial adalah sebagai berikut:

Hipotesis:

$H_{0}: \beta_{k}=0$ (variabel bebas ke- $k$ tidak berpengaruh terhadap variabel terikat)

$H_{1}: \beta_{k} \neq 0$ untuk $k=1,2, \ldots, p-1$ (variabel bebas ke- $k$ berpengaruh terhadap variabel terikat)

Taraf signifikansi $\alpha=0,05$

Statistik uji :

$$
W^{2}=\left(\frac{\widehat{\beta_{k}}}{S E\left(\widehat{\beta_{k}}\right)}\right)^{2}
$$

Penentuan titik kritik

Tolak $H_{0}$ jika $W_{\text {hitung }}^{2}>\chi_{\left(\alpha_{1}, 1\right)}^{2}$ atau $p$-value $<\alpha$

2.6. Metode Penelitian. Data penelitian ini diambil dari data nasabah yang terdaftar menjadi nasabah asuransi. Data penelitian ini berasal dari PT. Asuransi BRI Life Cabang 
Jember tahun 2007-2018. Data berupa data sekunder yang diperoleh dari data nasabah asuransi sebanyak 155 nasabah tentang jangka waktu kemampuan nasabah dalam melakukan pembayaran premi asuransi. Variabel yang digunakan dalam penelitian ini yaitu sebagai berikut:

1. Variabel tak bebas $(Y)$ adalah jangka waktu kemampuan nasabah melakukan pembayaran premi

2. Jenis $\operatorname{Kelamin}\left(X_{1}\right)$

3. Usia $\left(X_{2}\right)$

4. Uang Pertanggungan $\left(X_{3}\right)$

5. Pekerjaan $\left(X_{4}\right)$

6. Cara Pembayaran Premi $\left(X_{5}\right)$

7. $\operatorname{Premi}\left(X_{6}\right)$

8. Produk Asuransi $\left(X_{7}\right)$

Tahap-tahap yang dilakukan dalam penelitian ini antara lain:

a) Menganalisis variabel-variabel yang mempengaruhi jangka waktu kemampuan nasabah dalam membayar premi.

b) Menentukan nilai dan plot fungsi survival dan fungsi hazard tiap variabel bebas.

c) Melakukan uji asumsi proportional hazard.

d) Pembentukan model awal Cox proportional hazard.

e) Uji signifikansi secara serentak dan parsial.

f) Pembentukan model akhir dari model Cox proportional hazard.

\section{Hasil dan Pembahasan}

Kejadian yang diamati pada penelitian ini yaitu nasabah yang tidak mampu melakukan pembayaran premi asuransi pada PT. Asuransi BRI Life Cabang Jember pada tahun 2007-2018. Data ini meliputi jenis kelamin, usia, uang pertanggungan, pekerjaan, cara pemabayaran premi, premi, dan produk asuransi. Adapun kejadian yang diamati adalah faktor yang mempengaruhi nasabah tidak mampu melakukan pembayaran premi asuransi dengan status mampu membayar $=0$ (Inforce, Maturity, Inforce-Masa Bayar 
Selesai) dan tidak mampu membayar 1 (Surrender-Normal, Lapse Otomatis). Hasil yang diperoleh dari program $\mathrm{R}$ untuk setiap variabel yang diteliti adalah:.

a) Analisis Deskriptif Tiap Variabel Bebas

Tabel 1. Analisis Deskriptif Variabel Jenis Kelamin

\begin{tabular}{ccccc}
\hline & & \multicolumn{2}{c}{ Status } & \\
\cline { 3 - 4 } Kategori & $\begin{array}{c}\text { Jumlah } \\
\text { Nasabah }\end{array}$ & $\begin{array}{c}\text { Mampu } \\
\text { (Sensor) }\end{array}$ & $\begin{array}{c}\text { Tidak } \\
\text { Mampu } \\
\text { (Event) }\end{array}$ & Mean \\
\hline Perempuan & 63 & 21 & 42 & 0,67 \\
Laki-laki & 92 & 41 & 51 & 0,55 \\
\hline
\end{tabular}

Berdasarkan Tabel 1, terlihat bahwa jumlah nasabah jenis kelamin perempuan mempunyai proporsi lebih besar tidak mampu melakukan pembayaran premi sesuai jangka waktu dari pada nasabah jenis kelamin laki-laki yaitu 66,67\% sedangkan untuk laki-laki $55,43 \%$.

b) Plot Fungsi Survival dan Fungsi Hazard

Fungsi survival digunakan untuk mengetahui probabilitas kemampuan nasabah dalam membayar premi asuransi dan fungsi hazard digunakan untuk mengetahui risiko tingkat ketidakmampuan nasabah dalam melakukan pembayaran premi asuransi.

Tabel 2. Fungsi survival dan fungsi hazard nasabah perempuan

\begin{tabular}{ccccccc}
\hline$t_{j}$ & $n_{j}$ & $d_{j}$ & $\left(n_{j}-d_{j}\right) / n_{j}$ & $\hat{S}(t)$ & $\hat{h}(t)$ & $\widehat{H}(t)$ \\
\hline 1 & 63 & 19 & 0,7 & 0,7 & 0,3 & 0,16 \\
2 & 40 & 7 & 0,83 & 0,58 & 0,42 & 0,24 \\
3 & 33 & 3 & 0,91 & 0,52 & 0,48 & 0,28 \\
4 & 30 & 6 & 0,8 & 0,42 & 0,58 & 0,38 \\
5 & 23 & 1 & 0,96 & 0,4 & 0,6 & 0,4 \\
6 & 14 & 2 & 0,86 & 0,34 & 0,66 & 0,46 \\
8 & 12 & 2 & 0,83 & 0,29 & 0,71 & 0,54 \\
10 & 10 & 2 & 0,8 & 0,23 & 0,77 & 0,64 \\
\hline
\end{tabular}

Berdasarkan Tabel 2, untuk nasabah dengan kategori jenis kelamin perempuan didapatkan nilai $\hat{S}(t)$ untuk fungsi survival pertama yaitu 0,7 artinya nasabah dengan kategori jenis kelamin perempuan mempunyai peluang mampu membayar premi asuransi sebesar 70\% pada waktu survival pertama (1 tahun) dan sebanyak 63 nasabah. 
Banyaknya nasabah yang tidak mampu membayar premi asuransi dapat dilihat pada kolom $d_{j}$ dan jumlah nasabah yang berisiko tidak mampu membayar premi dapat dilihat pada kolom $n_{j}$. Nilai kumulatif hazard $\widehat{H}(t)$ diperoleh 0,16 artinya risiko nasabah tidak mampu membayar premi asuransi kumulatif dari waktu survival pertama yaitu $16 \%$. Nilai hazard $\hat{h}(t)$ pada waktu survival pertama yaitu 0,3 yang artinya risiko nasabah tidak mampu membayar premi asuransi pertama adalah $30 \%$.

Tabel 3. Fungsi survival dan fungsi hazard nasabah laki-laki

\begin{tabular}{ccccccc}
\hline$t_{j}$ & $n_{j}$ & $d_{j}$ & $\left(n_{j}-d_{j}\right) / n_{j} \hat{S}(t)$ & $\hat{h}(t)$ & $\widehat{H}(t)$ \\
\hline 1 & 92 & 13 & 0,86 & 0,86 & 0,14 & 0,07 \\
2 & 69 & 17 & 0,75 & 0,65 & 0,35 & 0,19 \\
3 & 51 & 8 & 0,84 & 0,55 & 0,45 & 0,26 \\
4 & 43 & 1 & 0,98 & 0,53 & 0,47 & 0,27 \\
5 & 41 & 2 & 0,95 & 0,51 & 0,49 & 0,3 \\
6 & 35 & 2 & 0,94 & 0,48 & 0,52 & 0,32 \\
7 & 33 & 2 & 0,94 & 0,45 & 0,55 & 0,35 \\
8 & 31 & 5 & 0,84 & 0,38 & 0,62 & 0,42 \\
9 & 24 & 1 & 0,96 & 0,36 & 0,64 & 0,44 \\
\hline
\end{tabular}

Berdasarkan Tabel 3, untuk nasabah dengan kategori jenis kelamin laki-laki didapatkan nilai $\hat{S}(t)$ untuk fungsi survival pertama yaitu 0,86 artinya nasabah dengan kategori jenis kelamin laki-laki mempunyai peluang mampu membayar premi asuransi sebesar $86 \%$ pada waktu survival pertama (1 tahun) dan sebanyak 92 nasabah. Nilai kumulatif hazard $\widehat{H}(t)$ diperoleh 0,07 artinya risiko nasabah tidak mampu membayar premi asuransi kumulatif dari waktu survival pertama yaitu 7\%. Nilai hazard $\hat{h}(t)$ pada waktu survival pertama yaitu 0,14 yang artinya risiko nasabah tidak mampu membayar premi asuransi pertama adalah 14\%. Dari Tabel 2 dan 3, terlihat bahwa peluang kemampuan nasabah untuk membayar premi asuransi semakin kecil. Sebaliknya, semakin lama nasabah menjadi nasabah asuransi, maka semakin tinggi risiko tingkat ketidakmampuan nasabah untuk membayar premi asuransi. Hal ini dapat disimpulkan bahwa probabilitas kemampuan nasabah membayar premi asuransi berbanding terbalik dengan tingkat kemampuan nasabah dalam membayar premi asuransi. Hasil plot dari estimasi fungsi survival dan fungsi hazard. 

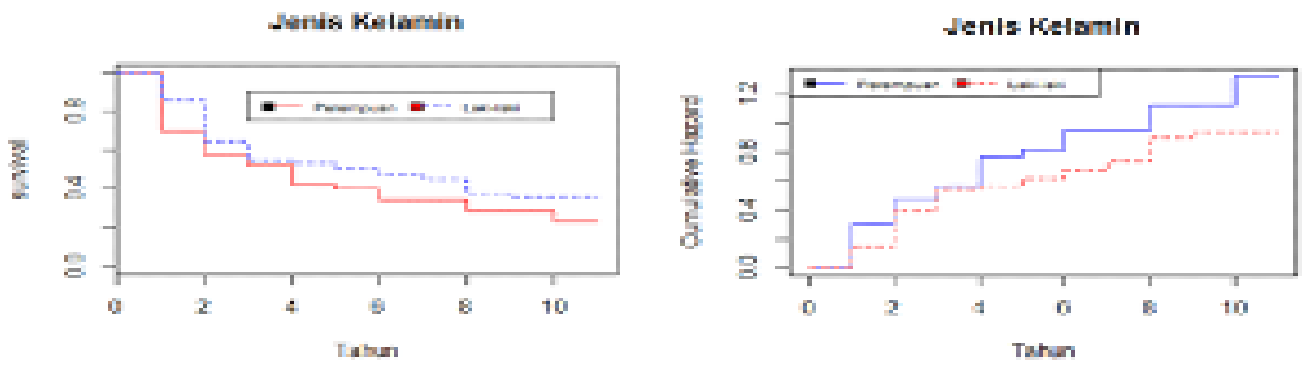

Gambar 1. Plot fungsi survival dan fungsi hazard variabel jenis kelamin

\section{a) Uji Asumsi Proportional Hazard}

Pengujian asumsi proportional hazard pada penelitian ini dilakukan dengan goodness of fit test menggunakan uji residu Schoenfield. Adapun hasil dari uji asumsi dengan goodness of fit test pada setiap variabel adalah:

Tabel 4. Uji Asumsi Proportional Hazard menggunakan uji residu Schoenfield

\begin{tabular}{lccc}
\hline \multicolumn{1}{c}{ Variabel } & Kolerasi & $p$-value & Keputusan \\
\hline Jenis Kelamin 2 & $-0,022$ & 0,811 & Terima $H_{0}$ \\
Usia 2 & 0,064 & 0,990 & Terima $H_{0}$ \\
Usia 3 & 0,016 & 1,000 & Terima $H_{0}$ \\
Usia 4 & $-0,042$ & 0,990 & Terima $H_{0}$ \\
Uang Pertanggungan 2 & $-0,100$ & 0,245 & Terima $H_{0}$ \\
Uang Pertanggungan 3 & $-0,108$ & 0,216 & Terima $H_{0}$ \\
Uang Pertanggungan 4 & $-0,159$ & 0,082 & Terima $H_{0}$ \\
Pekerjaan 2 & $-0,046$ & 0,624 & Terima $H_{0}$ \\
Pekerjaan 3 & $-0,111$ & 0,230 & Terima $H_{0}$ \\
Pekerjaan 4 & $-0,058$ & 0,537 & Terima $H_{0}$ \\
Pekerjaan 5 & $-0,091$ & 0,313 & Terima $H_{0}$ \\
Cara Pembayaran Premi 2 & 0,050 & 0,619 & Terima $H_{0}$ \\
Cara Pembayaran Premi 3 & 0,004 & 0,967 & Terima $H_{0}$ \\
Cara Pembayaran Premi 4 & 0,03 & 0,787 & Terima $H_{0}$ \\
Premi 2 & 0,11 & 0,249 & Terima $H_{0}$ \\
Premi 3 & 0,04 & 0,610 & Terima $H_{0}$ \\
Premi 4 & 0,15 & 0,100 & Terima $H_{0}$ \\
Premi 5 & 0,13 & 0,174 & Terima $H_{0}$ \\
Premi 6 & 0,16 & 0,095 & Terima $H_{0}$ \\
Produk Asuransi 2 & $-0,11$ & 0,990 & Terima $H_{0}$ \\
Produk Asuransi 3 & 0,04 & 0,990 & Terima $H_{0}$ \\
Produk Asuransi 4 & $-0,09$ & 0,343 & Terima $H_{0}$ \\
Produk Asuransi 5 & $-0,15$ & 0,126 & Terima $H_{0}$ \\
Produk Asuransi 6 & $-0,14$ & 0,142 & Terima $H_{0}$ \\
Produk Asuransi 7 & $-0,06$ & 0,501 & Terima $H_{0}$ \\
Produk Asuransi 8 & $-0,16$ & 0,101 & Terima $H_{0}$ \\
Produk Asuransi 9 & $-0,08$ & 0,437 & Terima $H_{0}$ \\
\hline & & &
\end{tabular}


Berdasarkan Tabel 4, kategori pada setiap variabel memiliki nilai $p$-value yang lebih besar dari nilai taraf signifikan $\alpha=0,05$ yang berarti terima hipotesis null. Terima $H_{0}$ atau terima hipotesis null dikatakan memenuhi asumsi proportional hazard apabila tidak ada korelasi antara rank waktu survival dan residu Schoenfield atau $r=0$ untuk masingmasing variabel, sehingga masing-masing variabel tidak bergantung pada waktu ketahanan. Semua kategori dari 7 variabel pada Tabel 4, yaitu variabel jenis kelamin, usia, uang pertanggungan, pekerjaan, cara pembayaran premi, premi, dan produk asuransi menunjukkan bahwa nilai dari $p$-value telah memenuhi kriteria uji yang ditentukan pada uji residu Schoenfield yaitu nilai $p$-value $>\alpha=0,05$, maka diperoleh keputusan terima $H_{0}$ yang artinya hasil dari uji residu Schoenfiled $r=0$ yaitu asumsi proportional hazard terpenuhi. Dapat disimpulkan bahwa semua kategori dalam variabel sesuai dengan krtiteria uji residu Schoenfiled dan mengakibatkan model sesuai dengan data yang diperoleh.

a.) Pembentukan Model Awal

Tabel 5. Estimasi Parameter Model Cox dengan metode Breslow

\begin{tabular}{ccccc}
\hline Variabel & Koef & $\exp \beta_{p}$ & SE & $p>|z|$ \\
\hline Jenis Kelamin & $-0,39122$ & 0,67623 & 0,2150 & 0,0688 \\
Usia & $-0,44765$ & 0,63913 & 0,2365 & 0,0584 \\
Uang Pertanggungan & 0,18341 & 1,20131 & 0,1901 & 0,3346 \\
Pekerjaan & $-0,22411$ & 0,79922 & 0,0891 & 0,0119 \\
Cara Pembayaran Premi & 0,30181 & 1,35231 & 0,1218 & 0,0132 \\
Premi & 0,10920 & 1,11539 & 0,1244 & 0,9801 \\
Produk Asuransi & 0,36407 & 1,43917 & 0,0746 & $1,05 \mathrm{E}-006$ \\
\hline
\end{tabular}

Diasumsikan semua variabel berpengaruh terhadap model, maka semua variabel dimasukkan dalam persamaan umum model Cox proportional hazard, sehingga diperoleh estimasi model awal Cox proportional hazard dengan metode Breslow berdasarkan Tabel 5.

$$
h(t, X)=h_{0}(t) \exp \left(-0,39122 X_{1}-0,44765 X_{2}+0,18341 X_{3}-0,22411 X_{4}+0,30181 X_{5}+0,10920 X_{6}-0,36407 X_{7}\right)
$$

\section{b.) Uji Signifikansi Parameter}

1. Uji Serentak

Uji signifikansi paramater dengan uji serentak dalam penelitian ini dilakukan untuk mengetahui apakah model pada Tabel 5 sudah tepat, maka dilakukan uji serentak 
menggunakan uji rasio likelihood yaitu sebagai berikut.

Hipotesis:

$H_{0}: \beta_{1}=\beta_{2}=\ldots=\beta_{7}=0$ (variabel yang tidak berpengaruh terhadap model)

$H_{1}$ : minimal ada satu $\beta_{i} \neq 0$, dengan $i=1,2,3,4,5,6,7$ (variabel yang berpengaruh terhadap model)

Taraf signifikan: $\alpha=0,05$

Statistik uji: Uji rasio likelihood

Penentuan titik kritik

Tolak $H_{0}$ jika $G_{\text {hitung }}^{2}>\chi_{\left(p_{i}, \varepsilon\right)}^{2}$ atau $p$-value $<\alpha$

Perhitungan:

Dari hasil output software $\mathrm{R}$ diperoleh $\ln L(\widehat{\Omega})=-425,2592$ dan $\ln L(\widehat{\omega})=-396,3562$ dengan nilai $p$-value adalah $4,132539 e^{-10}$, sehingga nilai dari uji rasio $\log$ likelihood adalah:

$$
\begin{aligned}
G^{2}=-2 \ln \left(\frac{L(\hat{\Omega})}{L(\hat{\omega})}\right) & =-2[\ln L(\widehat{\Omega})-\ln L(\widehat{\omega})] \\
& =-2\left[\ln (0)-\ln \left(X_{1} X_{2}, \ldots, X_{7}\right)\right] \\
& =-2[-425,2592-(-396,3562)] \\
& =57,806
\end{aligned}
$$

Karena $G^{2}=57,806>\chi_{(7 ; 0,05)}^{2}=14,067$ dan nilai $p$-value adalah $4,132539 e^{-10}<\alpha=0,05$ sehingga keputusan tolak $H_{0}$ dan dapat disimpulkan bahwa variabel $X_{1} X_{2} X_{3} X_{4} X_{5} X_{6} X_{7}$ minimal ada satu yang berpengaruh signifikan terhadap model.

2. Uji Parsial

Uji signifikansi parameter dengan uji Wald dalam penelitian ini yaitu untuk mengetahui variabel mana yang berpengaruh signifikan terhadap model Cox proportional hazard. Adapun hasil dari uji signifikansi secara parsial dengan uji Wald pada Tabel 6 .

Dari hasil uji Wald tersebut menunjukkan bahwa variabel $X_{3_{3}} X_{5_{2}} X_{6} X_{7}$ berpengaruh signifikan terhadap model Cox proportional hazard pada tingkat signifikansi $\alpha=0,05$ yaitu variabel uang pertanggungan, cara pembayaran premi, premi, dan produk asuransi karena nilai $p$-value $<\alpha=0,05$ dan nilai $W_{\text {hitung }}^{2}>\chi_{\left(\alpha_{i} 1\right)}^{2}$. 
Tabel 6. Hasil Pengujian Paramater Secara Parsial dengan Uji Wald

\begin{tabular}{cccccc}
\hline Variabel & $\beta$ & df & $\begin{array}{c}\text { Wald } \\
\left(W^{2}\right)\end{array}$ & $p$-value & Keputusan \\
\hline Jenis Kelamin $\left(X_{1}\right)$ & $-0,33130$ & 1 & 2,5 & 0,1135 & Tidak Signifikan \\
$\operatorname{Usia}\left(X_{2}\right)$ & $-0,09171$ & 1 & 0,18 & 0,6685 & Tidak Signifikan \\
Uang Pertanggungan $\left(X_{3}\right)$ & 0,44960 & 1 & 13,05 & 0,0003034 & Signifikan \\
Pekerjaan $\left(X_{4}\right)$ & $-0,10680$ & 1 & 1,67 & 0,1957 & Tidak Signifikan \\
Cara Pembayaran Premi $\left(X_{5}\right)$ & 0,38320 & 1 & 11,81 & 0,000589 & Signifikan \\
Premi $\left(X_{6}\right)$ & 0,25202 & 1 & 9,12 & 0,002532 & Signifikan \\
Produk Asuransi $\left(X_{7}\right)$ & 0,37524 & 1 & 28,87 & $7,76 \mathrm{E}-008$ & Signifikan \\
\hline
\end{tabular}

c.) Model Akhir

Setelah diuji secara parsial dan serentak didapat bahwa faktor-faktor yang mempengaruhi kemampuan nasabah dalam melakukan pembayaran premi asuransi adalah $\left(X_{3}\right)$ atau uang pertanggungan, $\left(X_{5}\right)$ atau cara pembayaran premi, $\left(X_{6}\right)$ atau premi, dan $\left(X_{7}\right)$ atau produk asuransi. Jadi dapat disimpulkan bahwa variabel uang pertanggungan, cara pembayaran premi, premi, dan produk asuransi berpengaruh terhadap jangka waktu kemampuan nasabah dalam pembayaran premi asuransi. Model akhir regresi Cox proportional hazard pada penelitian ini adalah

$$
h(t, X)=h_{0}(t) \exp \left(0,4496 \mathrm{X}_{3}+0,3832 \mathrm{X}_{5}+0,25202 \mathrm{X}_{6}+0,337524 \mathrm{X}_{7}\right)
$$

\section{Kesimpulan}

Faktor yang berpengaruh terhadap premi asuransi jiwa adalah $\left(X_{3}\right)$ atau uang pertanggungan, $\left(X_{5}\right)$ atau cara pembayaran premi, $\left(X_{6}\right)$ atau premi, dan $\left(X_{7}\right)$ atau produk asuransi. Model akhir regresi Cox proportional hazard pada penelitian ini adalah

$$
h(t, X)=h_{0}(t) \exp \left(0,4496 \mathrm{X}_{3}+0,3832 \mathrm{X}_{5}+0,25202 \mathrm{X}_{6}+0,337524 \mathrm{X}_{7}\right)
$$

\section{Daftar Pustaka}

[1] Rido, R. Hukum Dagang: Tentang Aspek-aspek Hukum Asuransi Udara, Asuransi Jiwa, dan Perkembangan Perseroan Terbatas. Bandung. 1986.

[2] Collett, D. Modelling Survival Data in Medical Research. London: Chapman and Hall. 2003.

[3] Lee, E. T. and Wang, J.W. Statistical Methods for Survival Data Analysis Third 
Edition. New Jersey: John Wiley \& Sons, Inc. 2003.

[4] Kleinbaum, D. G. and Klein, M. Survival Analysis A Self-Learning Text second edition. New York: Springer Science Business Media, Inc. 2005.

[5] Hanni, T. dan Wuryandari, T. Model Regresi Cox Proporsional Hazard Pada Data Ketahanan Hidup. Jurnal Media Statistika. Vol. 6(1): 11-20. 2013.

[6] Gail, M., Krickeberg, K., Samet, J., Tsiatis, A., and Wong, W. Statistics for Biology and Health. United States of America (USA): Springer. 2005.

[7] Cox and Oakes, D. Analysis of Survival Data. London: Chapman and Hall. 1984. 